\title{
The Prognoses of the 2011 Electoral Violence in Nigeria and the Lessons for the Future
}

\author{
Timothy Onimisi \\ Department of Political Science, Federal University Lokoja, Nigeria, P.M.Box 1154, Lokoja \\ timothyonimisi@yahoo.com
}

\section{Doi:10.5901/mjss.2015.v6n1s1p242}

\begin{abstract}
Elections is undisputable an essential element of democracy. Election through the ballot is strongly recognized as the only credible barometer to determine power sharing and one of the most important features of democratic transition in free and fair election. However the Nigeria electoral process over the years is characterized by thuggery, intimidation, insecurity, rigging, snatching of ballot box and killing. This paper employed a secondary source of data collection in examining the Nigerian electoral violence with a closer look at the 2011 general elections which was adjudged by many observers as the most credible and fairest in Nigerian history, and ironically the election was among the bloodiest ever in the country. The studies assess the causes and gravity of the 2011 electoral violence with a view to recommending ways of curbing future recurrence
\end{abstract}

Keyword: Election, Violence, Electoral Violence, Democracy

\section{Introduction}

Elections is an etiquette for any democracy. Election involve a set of activities leading to the selection of one more persons out of many to serve in positions of authority in a society (Orji and Uzodi, 2012). In any objective political arrangement all over the world, election through the ballot is strongly recognizes as the on credible barometer to power equation (Olasunkanmi, 2001). The intensified world struggle by people for free and fair elections, often at great personal risk, demonstrates how important this process has become to individuals everywhere (Laden, 2007).

The biggest of the challenges facing Nigeria today is how to choose leader at the different levels of government through a free and fair elections. The imperative of free and fair elections is better captured by former President of Nigeria Yar'Adua when he state

"... electoral reform is predicated on the belief that elections are the very heart of democracy hence they must not only be fair but they must be seen to be so by our people and the rest of the world" (Cited by Olasunkannmi, 2010)

A free and fair elections must be characterized by the absence of intimidation and the presence of wide range of fundamental human right, such as the rights to free expression, information, opinion, assembly, association and the production from violence and all forms of discrimination (Laden, 2007).

However, the Nigerian electoral process over the years has been characterized by thuggery, intimidation, insecurity, rigging, snatching of ballot box and killing. Hence the focus of this paper is to examine the Nigerian electoral violence with a closer look at the 2011 general elections which was adjudged by many observers as the most credible and fairest in Nigeria's history and ironically the election was among the bloodiest ever in the history of the country democratic process. The study employed a secondary source of data collection in assesses the cause and the gravity of the violence that associated with the election with a view to providing viable recommendation in order to preventing the recurrence.

\section{Conceptualization}

\subsection{Election}

Election in the parlance of Oxford Advance Learner's dictionary (2010) sees it as the process of choosing a person or a group of people for a position, especially a political position, by voting. It is clear that voting is an important element of election as Huntington (1991) explain that democratic system is the extent to which the most powerful collective decision makers are selected through fair, honest and periodic elections in which candidates freely compete for votes, and in 
which virtually all the adult population in eligible to vote.

Election is a procedure that allows members of an organization or community to choose representatives who will hold positions of authority within it (Encarta, 2009). Election is the process of elite selection by the mass of the population in any given system (Anifowoso, 2003). Hence, elections determine the rightful way of ensuring that responsible leaders to take over the mantle of the people concerning who govern at these levels serves as an opportunity for the public to make choices about the policies, programs, and future directions of government action (Encarta, 2009). Election is a major instrument for the recruitment of political leadership in democratic societies; the key to participation in democracy; and they way of giving consent to government (Dye, 2001); and allowing the governed to choose and pass judgment on office holders who theoretically represent the governed (Rose, 1978) (Cited in Onebamhoi, 2011).

\subsection{Electoral Violence}

Violence is the physical or emotional force and energy. It is caused by physical force that is intended to hurt or kill somebody (Oxford, 2010). Balogun (2003), sees electoral violence as all forms of violence (physical, psychological, administrative, legal and structural) at different stages engaged in by participants, their supporters and sympathizer (including security and election management body staff) in the electoral process. Nwolise (2007) captures the whole process of electoral violence in three (3) dimension and component as presented in the table below:

Table 1: Some components of the dimensions of electoral violence

\begin{tabular}{|c|c|}
\hline Dimension & Components \\
\hline \multirow[t]{12}{*}{ PHYSICAL } & Physical assault on individuals during campaign, elections and when election results are released. \\
\hline & Assassination of political opponents or people perceived as a threat to one's political ambition \\
\hline & Burning down of public or opponents houses or cars \\
\hline & Shooting, shoot-outs. \\
\hline & Killing of individuals. \\
\hline & Partisan harassment by security agents arrest, forceful dispersal of rallies, or shooting, wounding or killing of people. \\
\hline & Kidnapping and hostage-taking \\
\hline & Bombing of infrastructure. \\
\hline & Forceful disruption by thugs of political and campaign rallies \\
\hline & Destruction of ballot boxes and ballot papers by thugs or partisan security agents. \\
\hline & Armed raid on voting and collection centres, and snatching of ballot boxes and papers from polling agents \\
\hline & Free -for-all fights. \\
\hline \multirow[t]{6}{*}{ PSYCHOLOGICAL } & Threats against and harassment by security agents of opponents of the ruling regime or party, which create political apathy. \\
\hline & Shoot-on-sight orders that breed fear in voters. \\
\hline & Terror inflicted by political assassinations, which makes people scared to participate in politics or elections. \\
\hline & Publication or broadcast of abusive insulting, or intimidating material or advertorials \\
\hline & Threats to life through phone calls, text messages, etc \\
\hline & Threats to life through phone calls, text messages, etc. \\
\hline \multirow[t]{17}{*}{ STRUCTURAL } & Coercion of citizens by government to register or vote. \\
\hline & Exclusionary acts and policies. \\
\hline & Unequal opportunities for political parties and candidates \\
\hline & Deliberate changes in dates, venues, or times of events to the disadvantage of others. \\
\hline & Partisan delimitation of electoral constituencies and location of pooling boots. \\
\hline & Excessive fees for collecting party nomination forms \\
\hline & Unfree campaign \\
\hline & Reliance on money and brute force instead of moral integrity and competence. \\
\hline & Restraints imposed on voters \\
\hline & Use of the incumbency factor to give undue advantage to some candidates \\
\hline & Announcement of false or fraudulent results \\
\hline & Lengthy delays in announcing election results \\
\hline & Absence of (adequate) voting materials and election result forms \\
\hline & Delays in voting \\
\hline & Absence of electoral officers from pooling booths \\
\hline & Partisan behaviour of police and other security agents. \\
\hline & Discriminatory acts and policies. \\
\hline
\end{tabular}

Source: Nwolise, O.B. "Electoral Violence and Nigeria's 2007 elections' Journal of African Elections Vol.6 No. 2 Oct. 2007 


\title{
2.3 The 2011 Electoral Violence In Nigeria
}

The fifty years of Nigerian independence from the British the British administration has only witness four (4) elected governments from an uninterrupted democratic process since 1999 till date. Elections to a great extend has being accepted as a means of change of government and an act of participation of the people towards this change. Unfortunately, violence has become part of the political culture in Nigeria such that all the elections are virtually violence ridden; this violence is manifest in all the three stages of election process', pre-election, during elections, and post election period (Laden, 2007). Election violence at the pre-election stage usually manifests in intra-party and inter-party clashes arising from struggles over party nomination and access to the electorate (Laden, 2007). Inflammatory rhetoric, attack the person of the politicians and party support usually characterized this stage (Sisk, 2008). At the election stage the stage the acts of violence often involve intimidation, ballot stuffing, and attack on officials and observers (Orji and Ugodi, 2012). The post election violence often including shooting, killings, arson, wanton destruction of property, usually perpetrated by officials and support different political parties (Adoke, 2011). It is of great important to note that the Nigerian general elections of 2011 can be regarded as the most deadly with all form of actions that constitute electoral violence. The violence that came after the 2011 election was clearly organized in some area, suggesting the influence and involvement of other organization like Boko Haram, Taleban, and Kala Kato (Lewis, 2011). The 2011 post election violence start in Bauchi and Gombe states, and quickly spread to other parts of Northern Nigeria such as kano, Adamawa, Niger, and Kaduna states (Orji and Ugodi, 2012).

The gravity of the violence was clearly captured by Umeagbalasi (2011) thus

\begin{abstract}
"...botched NASS poll, at least 5 lives were lost. On April 8, 2011 at least 13 lives were to the Suleja INEC's office bombing. On the April 9, 2011 rescheduled NASS poll, 39 lives were lost. On April16, 2011 presidential poll proper; at least 10 lives were lost. And in the earth shaking post prudential poll violence that engulfed over half of the 19 Northern Nigerian states including Kano, Kaduna, Sokoto, Bauchi, Adamawa, Nigeria, Taraba, etc which started in the evening of the presidential poll's day at least 250 to 300 lives was lost, with public and private properties including churches, palaces, mosques, residences and vehicular valued at over 7 Billion Naira (about 50 Million Dollar) destroyed, according to eyewitnesses, disaster management, and visual, audio-visual and written media sources..."
\end{abstract}

Among the victims of the targeted violence in the North are members of the National Youth Service Crops who acted as election workers and Volunteers (Nwakanwa, 2011). Public and Private properties worth over 2.3 Billion Naira (15 Million Dollar) including over 500 vehicles and tricycles burnt in Bayelsa state, South-South Nigeria, were lost to vandalism and arson in connection with the election violence (Umeagbalasi, 2011).

\section{Prognoses Of The 2011 Election Violence In Nigeria}

Violence has become part of the political culture in Nigeria such that all elections are virtually violence-ridden (Laden, 2007). One of the major cause of 2011 electoral violence in Nigeria was corruption. Alemika (2011), explain further

"The perception of politics and political office as investment and as an Avenue for the acquisition of extraordinary wealth through corruption, which is otherwise not possible through any form of legitimate vocation and enterprise. As a result of this perception and reality, Nigerian politiciansturn electioneering and elections into warfare in which violence and ethnic,religious and other forms of primordial sentiments and prejudices are employed"

An electoral abuse was another leading cause of violence in Nigeria's election. The possibilities of electoral abuse are endless, ranging from the dissemination of scurrilous rumours about candidates, and deliberately false campaign propaganda, stuffing the ballot box with fraudulent returns, dishonest counting or report of the vote (Laden, 2007), and the attitude of Ad-hoc staff to elections (Olasunkanmi, 2010). The Ad-hoc staff are not non permanent of the electoral commission, and because they are not permanent staff, they are easily influenced into electoral malpractices and in most cases not even available during proceeding at electoral at electoral tribunal (Olasunkani, 2010), all these negative attitude of the ad-hoc stuff appear at the 2011 general election.

The high rate of illiteracy, unemployment and poverty is a vital sign of underdevelopment (Orji and Ugodi, 2012). Electoral violence in Nigeria is mostly carried financed, and sometime, armed by politician, state officials, and party officials or their representative cause by the high level of poverty, illiteracy and unemployment in the country (Orji and Ugodi, 2012). Many of these youths who are jobless enter politics with the intents and purposes of causing confusion and violence (Adele, 2012). 
Ethnic politics is another leading cause of violence in Nigeria as it is oblivious that Nigeria has not being able to take away ethnic sentiment from their electioneering process. After the 2011 general elections some disgruntled elements rose up in the North chanting "Ba Muso" meaning they do not like or want the elected president because he is not from the Northern part of the country prompting violence in that part of the country (Adele, 2012).

The absence of internal democracy amongst the political parties in Nigeria is another cause of electoral violence. So far experience has shown that the processes by which candidate emerge from their political parties is open to manipulation (Olasunkanmi, 2010). The inability of many political parties in Nigeria to operate in a democratic manner introduces tension and violence in the electoral process (Orji and Ugodi, 2012).

\section{Conclusion and Recommentation}

It is clear that electoral violence especially as demonstrated in the 2011 general election in Nigeria remains one of biggest threat to democratic experiment in recent history. The nature, extent and magnitude of violence associated with elections in Nigeria are posing serious threat to the long-term Nation quest for stable democratic transition, as well as the attainment of the longtime goal of consolidated democracy (Malu, 2009). Is on this bases that the study recommendation the following measure to stop future current of these unfortunate violence

* Sensitization of citizenry on their electoral rights and duties as stated in the constitution and the Electoral Act

* Early preparation for future elections by the independent electoral commission and security agencies. Equally the electoral commission body should be made truly independent and the security agencies must prosecute the electoral offenders to serve as a deterrent others.

* There is need for government to provide employment opportunities for the youths, because when the youths are gainfully employed their mind will be far from unlawful activities and they can hardly be used by politician

* The civil society groups and the government agencies must be fully proactive in educating the masses on electoral matter and the need to Shawn violence

\section{References}

Adele, J. B. (2012) Electoral Violence and Nigeria's 2011 General Elections. International Review of Social Sciences and Humanities. Vol. 4, NO. 1. Pp.205-219

Adoke, M. (2011) Stemming Electoral Violence in Nigeria: A Focus on the Adequacy of the Law and Its Enforcement. Vanguard (Lagos), 8 September

Alemika, E. E. O. (2011) Post-Election Violence in Nigeria: Emerging Trend and Lesson Anifowose, R. (2003) Theoretical Perspective on Elections, in Anifowose, R. and Babawale

T. (eds.), General Elections and Democratic Consolidation in Nigeria, Nigeria: Friedrick Ebert

Balogun, T. (2003) Nigeria: Electoral Violence and National. Security http://aceproject.org/ero-Regions/Africa/NG/electoral-violence-Nigeria

Dye, R. Y. (20010 Politics in America, New Jersey: Prentice Hall, Upper Saddle Rivers Encarta Premium (2009)

Huntington, S. (1991) Democracy and Third Wave, Journal of Democracy, 2 (2)

Laden, T. M. (2007) Enforcement of Electoral Law and Combating Electoral Violence in Nigeria: Roleof the Police, INEC and the Judiciary. A Paper Presented in the International Conference on Assessing Democratic Development in Nigeria, 1999-2007, Kano, Nigeria

Lewis, P. M. (2011) Nigeria: Assessing Risks to Stability. A Review Report of the CSIS African program. Washington, DC: Centre for Strategic and International Studies

Malu, N. (2009) Proposal for a Survey on Youths' Involvement in Election Violence and Rigging in Nigeria http://www.panafstrag. org/download S/7/74. doc retrieved on April 02.2009

Nwakanwa, O. (2011) Post-Election Violence in Nigeria

Nwolise, O. B. (2007) Electoral Violence and Nigeria's 2007 Elections. Journal of Africa Elections Vol. 6 No. 2 Oct.

Olasunkanmi, O. (2010) Electoral Malpractices in Nigeria, Causes, Effects and Solution. A Paper Presented at the Sensitization and Training Course for Man O' War Nigeria, Oyo State

Onebamhoi, N. O. (2011) Curbing Electoral Violence in Nigeria: The Imperative of Political Education. International Multidisciplinary Journal, Ethiopia, Vol. 5 (5)

Orji, N. and Uzodi, N. (2012) Post Election Violence in Nigeria. Experiences with the 2011 Elections. Publishished by Policy and Legal Advocacy Centre (PLAC)

Oxford Advance Learners Dictionary (2010). Oxford University Press

Rose, R. (1978) "Is Choice Enough? Elections and Political Authority" in Hermet, G; Rose

R. and Rouquie A (eds.) Elections Without Choice. London: Macmillian. Pp 169-212

Umeagbalasi, E. (2011) How Over 500 Lives Were Lost To 2011 Election Violence in Nigeria. The International Society for Civil Liberties and the Rule of Law

Sisk, T. (2008) Elections in Fragile States: Between Voice and Violence. A Paper Presented at the International Studies Association Annual Meeting, San-Francisco, California 